J. Clin. Chem. Clin. Biochem.

Vol. 15, 1977, pp. 449-453

\title{
Consumptive Coagulopathy as Biochemical Mechanism in Oxygen Toxicity and its Enhancement by Lead(II) Ions
}

\author{
By L. A. Kiesow \\ Department of Experimental Medicine, Naval Medical Research Institute, Bethesda, Maryland 20014 U.S.A.
}

(Received February 1/May 17, 1977)

Dedicated to Ernst Schütte on the occasion of his becoming a professor emeritus of physiological chemistry

Summary: Consumptive coagulopathy and disseminated intravascular coagulation can be observed in rats exposed to 4 ata of oxygen. These events clearly precede the death of the animal and appear to be initiated by an activation of coagulation factor XII (Hageman). The onset and the extent of consumptive coagulopathy are greatly enhanced by a single and low intravenous dose of lead acetate. Mechanisms of activation of the intrinsic coagulation system and its role in oxygen toxicity are being discussed.

\section{Verbrauchskoagulopathie als biochemischer Mechanismus für die Toxizität von Sauerstoff und seine Verstärkung durch Blei (II)-ionen}

Zusammenfassung: Werden Ratten einem Sauerstoffdruck von 4 ata ausgesetzt, können Verbrauchskoagulopathie und disseminierte intravaskuläre Gerinnung beobachtet werden. Diese Erscheinungen sind deutliche Vorzeichen des Todes der Tiere und scheinen durch eine Aktivierung von Gerinnungsfaktor XII [Hageman] ausgelöst zu werden. Das Einsetzen und das Ausmạß der Verbrauchskoagulopathie werden durch eine geringe intravenöse Einzelgabe von Bleiacetat erheblich verstärkt. Der Aktivierungsmechanismus des intrinsic-Gerinnungssystems und seine Bedeutung für die Toxizität von Sauerstoff werden diskutiert.

\section{Introduction}

Man and many animals, when exposed to oxygen partial pressures $\left(\mathrm{pO}_{2}\right)$ greater than that of air at sea level, will suffer from various toxic effects of this exposure. Since Paul Bert's original demonstration in 1878 , these effects are summarized as "oxygen toxicity" (1). They are known to become more severe when either the $\mathrm{pO}_{2}$ or the duration of exposure are increased and are eventually leading to death. Oxygen toxicity may indeed have the potential to affect most cells, tissues and organs.(2). However, it should be emphasized that the low solubility of oxygen in water when combined with the physical chemistry and shape of the hemoglobin-oxygen equilibrium curve may severely reduce the actual exposure of many cells and tissues to exceedingly high $\mathrm{pO}_{2}$ values. Exceptional in this respect are, besides skin and eyes, the tissues of the respiratory tract including the lungs, the cells and components of blood and blood plasma, and the endothelial linings of the arterial blood vessels. These tissues will essentially equilibrate with the $\mathrm{pO}_{2}$ of the breathing gas. They may therefore provide both primary and early target sites for a progressing chain of cellular damage in oxygen toxicity. Furthermore, such primary damage may either by itself or by its involvement of other tissues lead - to death.

More recently it has been reported that a single and low intravenous dose of lead(II) ions $\left(\mathrm{Pb}^{2+}\right)$ can drastically shorten the survival time of rats exposed to increased $\mathrm{pO}_{2}(3,4)$. The mechanism of this synergistic effect of lead ions and $\mathrm{O}_{2}$ was first poorly understood; particularly, since several physiological and biochemical systems and functions failed to reveal any significant changes (4). Subsequent studies, however, disclosed an activation of the intrinsic coagulation pathway of the blood plasma to be synergistically enhanced by lead ions and increased $\mathrm{pO}_{2}$ leading to consumptive coagulopathy and disseminated intravascular coagulation (5). In addition, it was shown that the presence of a complete and factor competent intrinsic coagulation cascade was essential for this synergistic effect and that factor XII activity appeared to be of particular importance in the lead-enhanced development of consumptive coagulopathy. 
The present report will extend previous observations to substantially increased $\mathrm{pO}_{2}$ values and will discuss biochemical mechanisms by which $\mathrm{Pb}^{2+}$ and $\mathrm{O}_{2}$ enhance each others' activities synergistically.

\section{Materials and Methods}

Femoral cutdowns were performed on male Sprague-Dawley rats ( $200 \pm 20 \mathrm{~g}$; NMRI strain) under light ether anesthesia. Ten $\mathrm{mg}$ of lead acetate $\left(\mathrm{PbAc}_{2}\right)$ or equimolar sodium acetate ( $\left.\mathrm{NaAc}\right)$ dissolved in deionized $\mathrm{H}_{2} \mathrm{O}$ were given as a single $i$. $v$. injection. Groups of 6 animals were placed in a small hyperbaric animal chamber (Bethlehem) containing soda lime as $\mathrm{CO}_{2}$ scrubber. The chamber was flushed for $5 \mathrm{~min}$ with $100 \% \mathrm{O}_{2}$ at $\mathrm{l}$ ata and was then pressurized to 4 ata over a $3 \mathrm{~min}$ period. Subsequently it was vented with $\mathrm{O}_{2}$ at a $50 \mathrm{l}$ per min flow rate for $5 \mathrm{~min}$ which was then reduced to a maintenance vent rate of 11 per min. Temperature was maintained at $22 \pm 2{ }^{\circ} \mathrm{C}$.

Blood samples were obtained by cardiac puncture of properly decompressed animals $(0.031 \mathrm{ata} / \mathrm{s})$ under light ether anesthesia using siliconized needles and plastic syringes. Introduction of tissue thromboplastin was carefully avoided and initially sampled blood always discarded.

Coagulation assays were performed in the Clotek system (Hyland). Prothrombin times (PT) and activated partial thromboplastin times (APTT) were determined using standard techniques (6) and standard reagents (Dade; Hyland)

The activities of coagulation factors V, VII, VIII and XII were determined with factor deficient human plasma (Dade, SeraTech) using standard curves developed for the factor activities of rat plasma based on pooled, citrated rat plasma with $0.0284 \mathrm{~mol} / 1$ sodium barbital in $0.125 \mathrm{~mol} / 1 \mathrm{NaCl}, \mathrm{pH}=7.35$ as diluent. All assays were performed in triplicate.

Factor XII activation was determined as spontaneous clotpromoting activity of non-activated rat plasma in factor XII deficient human plasma using the methods of Cochrane \& Wuepper (7).

Fibrin monomers (FM) were assayed by the protamine sulfate test of Niewiarowski \& Gurevich (8). Fibrinogen/fibrin degradation products (FDP) were determined using the staphylococcal clumping test (9).

All chemicals were A. R. grades or otherwise of the highest purity available (Mallinckrodt, Baker).

\section{Results}

The exposure of rats that had been injected $18 \mathrm{~h}$ earlier with sodium acetate to 4 ata of $100 \% \mathrm{O}_{2}$ results in a gradual prolongation of both prothrombin time and activated partial thromboplastin time values of the blood plasmia obtained from decompressed animals (tab. 1). These increases, although already apparent after as short a hyperbaric exposure time as $60 \mathrm{~min}$, became statistically significant after $90 \mathrm{~min}$ of exposure. However, neither 60 nor 90 min of exposure time resulted in detectable levels of fibrin monomers (FM) or fibrinogen/fibrin degradation products (FDP) in any of the animals of the sodium acetate groups (tab. 1). Those animals that were given a single injection of lead acetate $18 \mathrm{~h}$ prior to their exposure to 4 ata $\mathrm{O}_{2}$ showed significantly prolonged prothrombin times and activated partial thromboplastin times at $60 \mathrm{~min}$ exposure time which became more prolonged with a further in- crease of the exposure to $90 \mathrm{~min}$ (tab. 1). Moreover, the treatment with $\mathrm{Pb}^{2+}$ resulted in an appearance of fibrin monomers in 50 percent of the animals at $60 \mathrm{~min}$ and in almost 90 percent at $90 \mathrm{~min}$ of hyperbaric $\mathrm{O}_{2}$ exposure (tab. 1). Fibrinogen/fibrin degradation products could also be detected in all animals of this group at both exposure times and at plasma concentrations exceeding $40 \mathrm{mg} / \mathrm{l}$. It should be noted that the absolute survival times of the animals of the sodium acetate groups were $265 \pm 76 \mathrm{~min}$ and of the lead acetate groups $146 \pm 35$ min respectively.

These results suggested an activation of the coagulation system to occur as an early response of rats to an exposure to 4 ata $\mathrm{pO}_{2}$ which could also be enhanced by $\mathrm{Pb}^{2+}$. Consequently, the plasma activities of coagulation factors XII, VIII, VII and V were determined in both groups of animals at both exposure times; i. e., 60 and $90 \mathrm{~min}$. It can be seen in figure 1 that an increased time of exposure to a $\mathrm{pO}_{2}$ of 4 ata results in decreased activities of all coagulation factors examined. Furthermore, a significant enhancement of this decrease in factor activities resulting from the administration of lead acetate was evident at both, 60 and $90 \mathrm{~min}$ of exposure (fig. 1). These observations seem to confirm an activation of the intrinsic coagulation system by hyperbaric $\mathrm{O}_{2}$ which can be greatly accelerated by a treatment with lead acetate and which leads to a rapid onset of consumptive coagulopathy.

Additional evidence for disseminated intravascular coagulation with a formation of microthrombi and fibrin deposits was obtained from electron-microscopic examination of various tissues and organs of animals after their exposure to 4 ata $\mathrm{O}_{2}$. Particularly the animals of the $\mathrm{Pb}^{2+}$ treated groups produced persistently pictures like those of figure 2 which shows intravascular fibrin deposits and microthrombi formation in the lungs of a $\mathrm{Pb}^{2+}$ treated rat after $90 \mathrm{~min}$ of exposure to 4 ata $\mathrm{pO}_{2}$. It should be mentioned that the frequency with which such pictures were observed in various organs of animals of the different experimental groups coincided well with the quantitative progression of all observed changes in the blood coagulation system of the respective groups.

Finally, it is shown in table 2 that, particularly in $\mathrm{Pb}^{2+}$ treated animals, an activation of coagulation factor XII (Hageman) can be demonstrated after an exposure to 4 ata of $\mathrm{O}_{2}$ of only $30 \mathrm{~min}$. This activation of factor XII, the triggering factor of the intrinsic coagulation cascade, was determined as clotpromoting activity of the rat plasma in Hageman factor deficient human plasma and was expressed as that fraction (in \%) of total factor XII activity which was spontaneously activated in vivo due to treatment and exposure of the animals. Such activation of factor XII would therefore indicate a hyper-coagulative state of the blood plasma. It would also point at Hageman factor as a primary and common action site for lead ions and hyperbaric $\mathrm{O}_{2}$. 
Tab. 1. Effect of lead acetate and 4 ata $\mathrm{O}_{2}$ on prothrombin time (PT), activated partial thromboplastin time (APTT), fibrin monomers (FM), and fibrin degradation products (FDP) in rats.

The number of animals per each experimental group was 24 . Controls consisted of sodium acetate, lead acetate and no treatment groups all of which produced similar values. The percentages of animals showing positive FM and FDP response are given in parentheses. All PT and APTT values are given as means \pm standard deviations. The absolute survival time of the sodium acetate group was $265 \pm 76 \mathrm{~min}$ and that of the lead acetate group was $146 \pm 35 \mathrm{~min}$.

\begin{tabular}{lllllr}
\hline Experimental Group & $\begin{array}{l}\text { Exposure Time } \\
(\mathrm{min})\end{array}$ & $\begin{array}{l}\text { PT } \\
(\mathrm{s})\end{array}$ & $\begin{array}{l}\text { APTT } \\
(\mathrm{s})\end{array}$ & $\begin{array}{l}\text { FM } \\
(+ \text { or }-)\end{array}$ & $\begin{array}{l}\text { FDP } \\
(\mathrm{mg} / \mathrm{l})\end{array}$ \\
\hline Controls & 0 & $20.7 \pm 3$ & $40.6 \pm 5$ & $-(0)$ & 0 \\
sodium acetate & 60 & $26.0 \pm 3$ & $60.6 \pm 7$ & $-(0)$ & $(0)$ \\
sodium acetate & 90 & $35.5 \pm 4$ & $100.6 \pm 7$ & $-(0)$ & 0 \\
lead acetate & 60 & $66.0 \pm 3$ & $171.3 \pm 6$ & $+(56)$ & $(0)$ \\
lead acetate & 90 & $119.2 \pm 4$ & $271.6 \pm 7$ & $+(86)$ & $40(100)$ \\
\hline
\end{tabular}
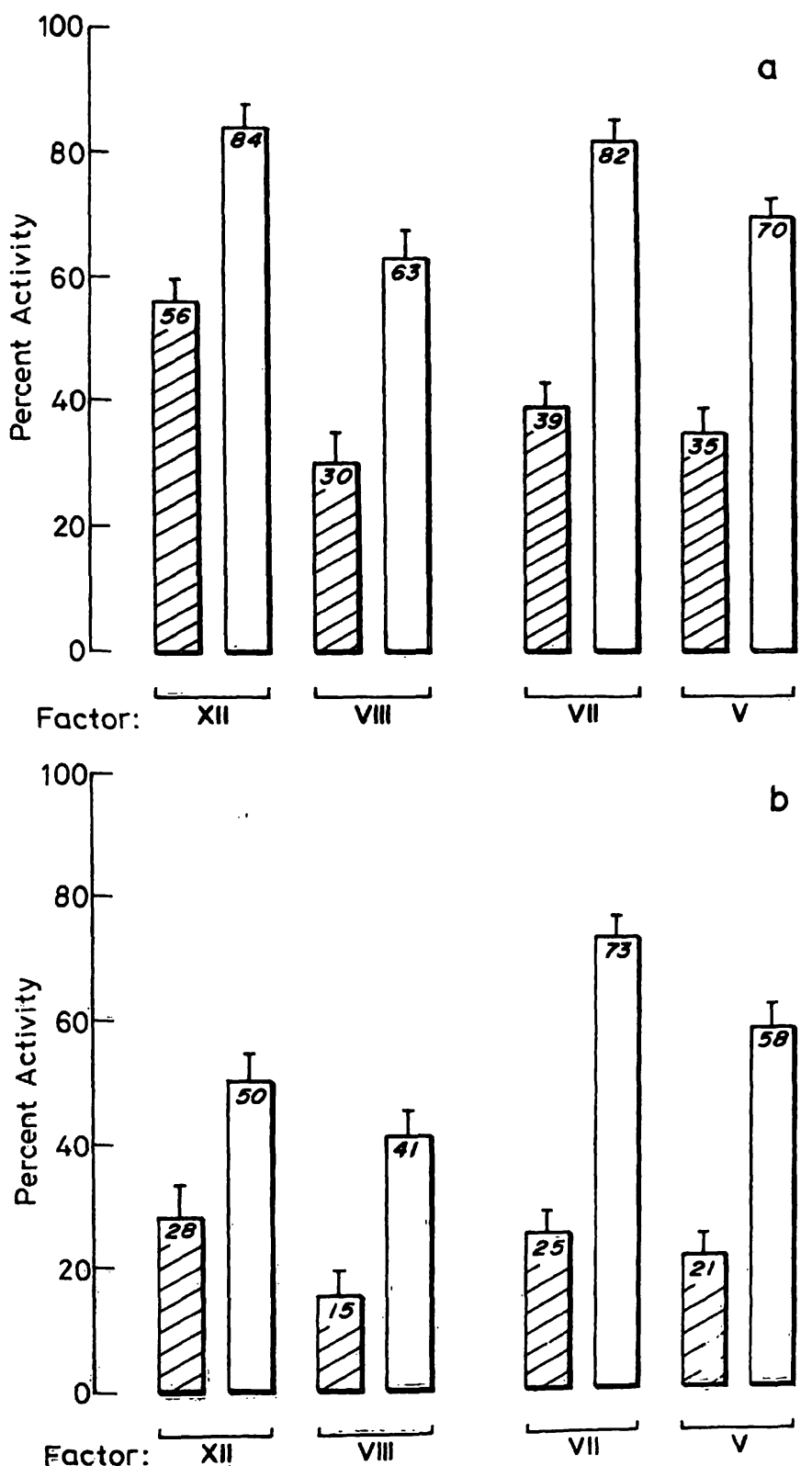

Fig. 1. The effects of lead acetate and/or exposure to 4 ata $\mathbf{O}_{2}$ for 60 and 90 min on coagulation factors XII, VIII, VII and $\mathrm{V}$ in rats.

The slanted numbers indicate the exact percentage of factor activities; the bars represent standard errors. The number of animals in each group was 24. Exposure times: (a) $=60 \mathrm{~min} ;(\mathrm{b})=90 \mathrm{~min}, \mathbb{Z}=$ lead acetate, $\square=$ sodium acetate.
Tab. 2. The in vivo activation of Factor XII (Hageman) in rats exposed to 4 ata $\mathrm{O}_{2}$ with or without lead acetate treatment.

The number of animals in each group was 12 . Controls include sodium acetate and lead acetate groups. Factor activity represents spontaneous in vivo activation as percentage of chemically in vitro activated total factor activity.

\begin{tabular}{lll}
\hline Experimental Group & Exposure Time & $\begin{array}{l}\text { Factor XII } \\
\text { Activity } \\
\text { (as\% of } \\
\text { max. activity) }\end{array}$ \\
\hline Controls & 0 & 0 \\
sodium acetate & 30 & $24 \pm 6$ \\
lead acetate & 30 & $62 \pm 8$ \\
\hline
\end{tabular}

\section{Discussion}

In view of previous observations, none of the findings reported here are completely unexpected. In fact, they appear to be logical extensions of earlier data (5) which they confirm at increased $\mathrm{pO}_{2}$ values and decreased exposure times and with which they are in agreement. Consequently, reference alone (5) may suffice in the context of this report and may thus provide room for the discussion of some additional consequences of these experiments not previously touched upon.

For example, the rapid activation and subsequent consumption of factor XII in animals exposed to 4 ata of $\mathrm{O}_{2}$ and the acceleration of these events by lead ions indicate not only an enhancing effect on one component of the intrinsic coagulation system but point also at a common primary action site in the blood plasma. It is therefore interesting to recall that the plasma of animals breathing hyperbaric $\mathrm{O}_{2}$ belongs to the few "tissues" that are indeed in equilibrium with high $\mathrm{O}_{2}$ pressures. Furthermore, blood provides, at least initially, most of the binding sites for which intravenous $\mathrm{Pb}^{2+}$ has extremely high affinities. Besides inorganic phosphate, these sites consist of sulfhydryl and phosphoryl groups of proteins (10) and their binding of $\mathrm{Pb}^{2+}$ may result in changes of protein function and structure. For coagulation factor XII this seems to result in a modified form 


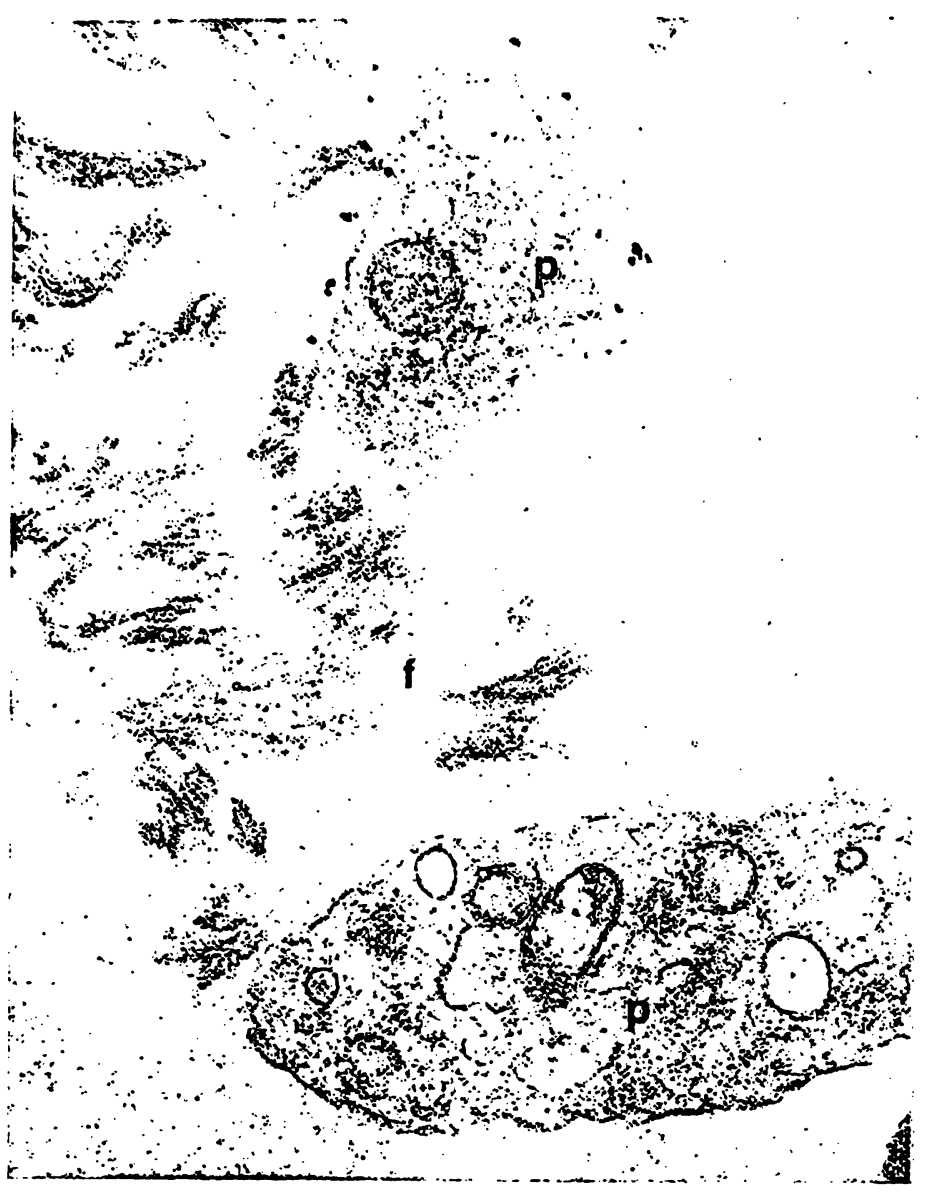

[0]

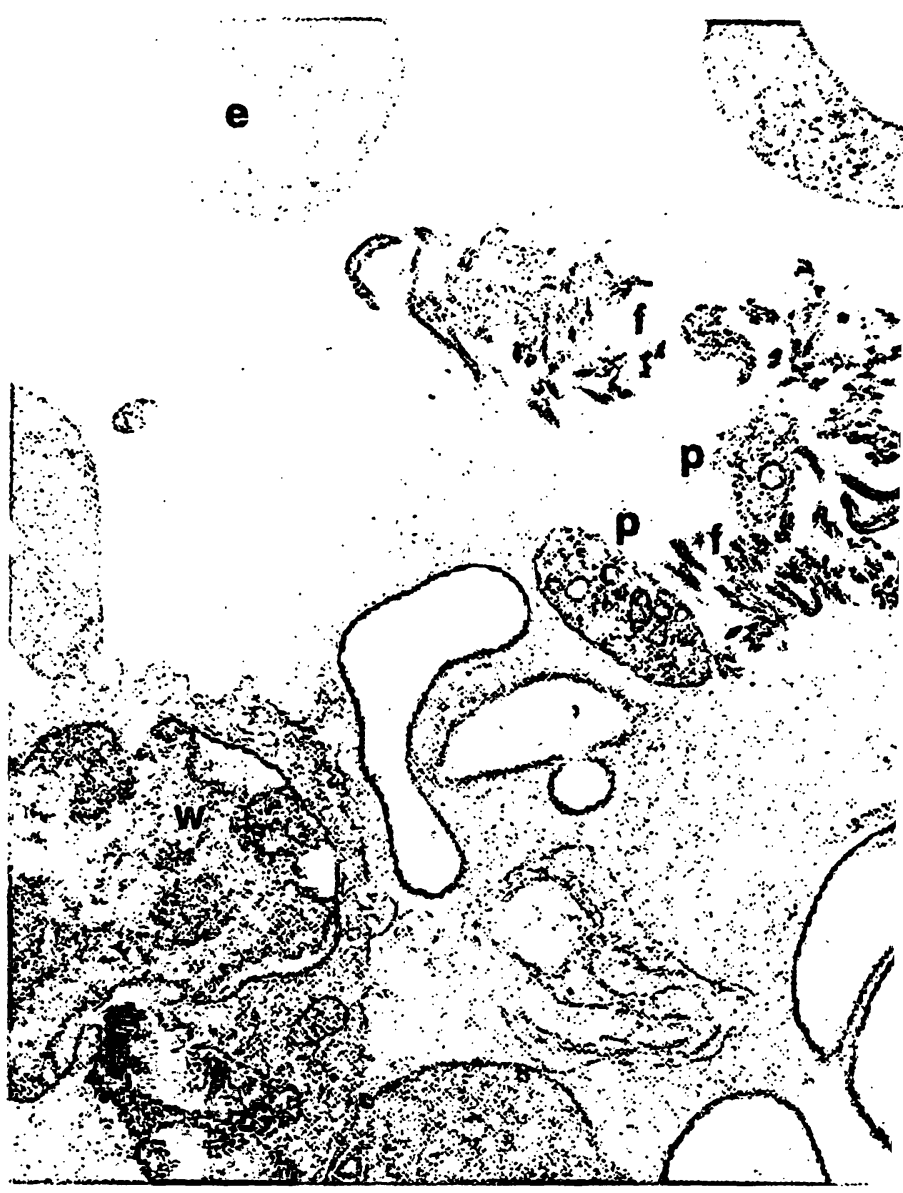

b

Fig. 2. Electron-micrographs of ultra-thin sections of lungs of lead acetate treated rats exposed to 4 ata $0_{2}$ for 90 min. The magnifications are: $a=70,000$-fold; $b=17,500$-fold. The following abbreviations are used: $e=$ erythrocyte; $f=$ fibrin; $\mathrm{p}=$ blood platelet; $\mathrm{w}=$ white blood cell.

that is not only readily activated by bacterial lipopolysaccharides (11), but also by $\mathrm{O}_{2}$ at partial pressures exceeding those of air at 1 ata. The exact chemical mechanism by which such different chemical entities as $\mathrm{Pb}^{2+}$ and $\mathrm{O}_{2}$ act on a protein is not yet known. However, hyperbaric $\mathrm{O}_{2}$ establishes its biochemical activities through oxidative and auto-oxidative (peroxidative) reactions which may also involve functional groups of $\mathrm{a}^{2+}$ modified protein of the Hageman factor leading to its activation.

At present it is difficult to assess what effects, if any, endothelial cells which may have been damaged by $\mathrm{Pb}^{2+}$ and $\mathrm{O}_{2}$ could have on the biochemical mechanics of an activation of the intrinsic coagulation system. However, the observed early activation of factor XII together with the general pattern of subsequent factor consumption in the development of disseminated intravascular coagulation suggest this contribution to be of rather limited significance. Yet, as a possibility it should not be excluded completely.

Finally, if an activation of the intrinsic coagulation pathway with consumptive coagulopathy and disseminated intravascular coagulation is indeed an early and essential phase in the establishment of oxygen toxicity, there are at least two interesting biological consequences that would follow:

(i) factor XII deficient animals which can not activate the intrinsic coagulation system should be quite resistant to hyperbaric $\mathrm{O}_{2}$;

(ii) animals that, in the course of their physiological activities, expose themselves to increased pulmonary $\mathrm{pO}_{2}$ values should be factor XII deficient.

A comparison of the mean survival times of several animal species in $100 \% \mathrm{O}_{2}(12)$ and the presence or absence of factor XII activity (tab. 3) permits indeed the formation of two groups.

One group is resistant to hyperbaric $\mathrm{O}_{2}$ and lacks Hageman factor while the other one with short $\mathrm{O}_{2}$ survival times shows Hageman factor activity. Moreover, animals that perform breathholding dives to considerable excursion depths like whales and porpoises the sperm whale has been reported to dive to a depth of $1000 \mathrm{~m}$ with $75 \mathrm{~min}$ of breathholding and the porpoise to $305 \mathrm{~m}$ with $6 \mathrm{~min}$ of breathholding (13) are also factor XII deficient (14). 
Tab. 3. Animal survival times in 1 ata $\mathrm{O}_{2}$ and Factor XII (Hageman) presence.

\begin{tabular}{|c|c|c|}
\hline Species & $\begin{array}{l}\text { Mean survival time }{ }^{\mathrm{a}} \\
\text { (h) }\end{array}$ & $\begin{array}{l}\text { Factor } \\
\mathbf{X I I} \underline{\mathbf{b}}\end{array}$ \\
\hline $\begin{array}{l}\text { Rat } \\
\text { Mouse } \\
\text { Guinea Pig } \\
\text { Rabbit } \\
\text { Dog } \\
\text { Cat }\end{array}$ & $\begin{array}{l}95 \\
92 \\
96 \\
77 \\
72 \\
83\end{array}$ & $\begin{array}{l}+ \\
+ \\
+ \\
+ \\
+ \\
+\end{array}$ \\
\hline $\begin{array}{l}\text { Frog } \\
\text { Turtle } \\
\text { Chicken } \\
\text { Duck }\end{array}$ & $\begin{array}{l}>1300 \\
>552 \\
>672 \\
>\quad 500\end{array}$ & $\begin{array}{l}- \\
- \\
-\end{array}$ \\
\hline $\begin{array}{l}\text { Whale } \\
\text { Porpoise }\end{array}$ & $\begin{array}{l}\text { N. D. } \\
\text { N. D. }\end{array}$ & $\overline{-}$ \\
\hline
\end{tabular}

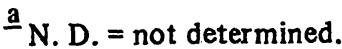

$\underline{b}+$ indicates Factor XII presence; - its absence.

These latter observations are clearly teleological in nature and may be more a curiosity of comparative biology. As such they may add little to this discussion and may even distract from the more serious pathophysiological consequences of the experimental data of this report. However, the growing use of hyperbaric oxygen in respirators, and even as treatment modality in hyperbaric chambers as well as the role of hyperbaric $\mathrm{O}_{2}$ as an occupational health hazard potentially affecting tunnel workers and divers attributes new importance to all facets of oxygen toxicity including those published here.

\section{Acknowledgements}

The experiments reported herein were conducted according to the principles set forth in the "Guide for the Care and Use of Laboratory Animals", Institute of Laboratory Animal Resources, National Research Council, DHEW Pub. No. (NIH) 74-23.

The author is indebted to Lt. Col. A. E. McKee, VC, USAF, Department of Experimental Pathology, Naval Medical Research Institute for the preparation and interpretation of numerous clectron-micrographs. He also likes to gratefully acknowledge the skilled assistance of Messrs J. W. Bless, B. F. Lindsley and $S$. Shapiro in the execution of the large number of experiments of this report.

\section{References}

1. Winter, P. M. \& Smith, G. (1972), Anesthesiol. 37, 210-241.

2. Haugaard, N. (1974), in Molecular Oxygen in Biology (Hayaishi, O., ed.), 163-182, North-Holland Publishing Company, Amsterdam.

3. Jones, R. B., Nelson, D. P., Shapiro, S. \& Kiesow, L. A. (1974), Experienta 30, 327-328.

4. Jones, R. B., Nelson, D. P., Shapiro, S. \& Kiesow, L. A. (1974), Fifth Intern. Hyperbaric Congr. Vol. 1, 165-171, Simon Fraser, Burnaby.

5. Kiesow, L. A., Shapiro, S., Lindsley, B. F. \& Bless, J. W. (1977), Thromb. Haemost. 37, 170-176.

6. Denson, K. W. E. (1976), in Human Blood Coagulation, Haemostasis and Thrombosis (Biggs, R., ed.), 2nd edit., 657-750, Blackwell Scientific Publ. Oxford.

7. Cochrane, C. G. \& Wuepper, K. D. (1971), J. Exp. Med. 134, 986-1004.

8. Niewiarowski, S. \& Gurewich, V. (1971), J. Lab. Clin. Med. $77,665-676$.

9. Hawiger, J., Niewiarowski, S., Gurewich, V. \& Thomas, D. P. (1970), J. Lab. Clin. Med. 75, 93-108.

10. Vallee, B. L. \& Ulmer, D. D. (1972), Ann. Rev. Biochem. 41, 91-128.

11. Jones, R. B. \& Kiesow, L. A. (1974), Infect. Immun. 10, 1343-1349.

12. Clark, J. M. \& Lambertsen, C. J. (1971), Pharmacol. Rev. $23,37-133$.

13. Strauss, M. (1970), Aerospace Med. 41, 1362-1381.

14. Ridgway, S. H., Simpson, J. G., Patton, G. S. \& Gilmartin, W. G. (1970), J. Am. Vet. Med. Ass. 157, 566-575.

L. A. Kiesow

Department of Experimental Medicine Naval Medical Research Institute Bethesda, Maryland 20014 U.S.A. 